\title{
Ultramountanism and Protestantism in the Regency period: an analyzes of priests Perereca and Tilbury critics of the Methodist mission in Brazil
}

Ultramontanismo e protestantismo no período regencial: uma análise da crítica panfletária dos padres Perereca e Tilbury à missão metodista no Brasil

\section{DOI: http://dx.doi.org/10.1590/2236-463320171505}

Ana Rosa Cloclet da Silva

Pontifícia Universidade Católica de Campinas - PUC/Campinas, Campinas - SP, Brasil anacloclet@gmail.com

Thaís da Rocha Carvalho Pontifícia Universidade Católica de Campinas - PUC/Campinas, Campinas - SP, Brasil thaiscarvalhosp@gmail.com

\begin{abstract}
Under the royalist model - which perpetuated the right of patronage and the Catholicism condition as the official religion of the Brazilian Empire - the clergy and laity who entered the new constitutional phase, occupying a prominent place in the representative sphere, discussed plural issues, including the theme of "'religious freedom", differently treated by representatives of the regalist and ultra-mountain Catholicism. Considering the historicity behaved for appropriation of the doctrines and the institutionalized practices that structure the religious field, this article analyzes a particular controversy, which polarized regalists and ultramountinists in the regency period: the arrival of Protestants in Brazil. It particularly examines the publications of two ultra-mountain publicist priests who stood out as the main opposition to the arrival of Methodists in Brazil: Luis Gonçalves dos Santos - nicknamed "Father Perereca"- and William Paul Tilbury, English priest who had emigrated to Brazil and here changed his name to Guilherme Paulo Tilbury. From a theoretical point of view, it relies on the pertinence of Pierre Bourdieu's theoretical tools, when dealing with the configuration of the "religious field" in Brazil in the first half of the nineteenth century, revealing the
\end{abstract}


nature of disputes over symbolic capital, interwoven with alternative models of the relationship between State and Church.

Resumo: Sob a longa vigência do modelo regalista - que perpetuou o direito do padroado e a condição do catolicismo como religião oficial do Império - os clérigos e leigos que adentraram a nova etapa constitucional debateram questões plurais, no âmbito das quais buscaram conciliar a defesa da religião como ingrediente indispensável à legitimação das novas formas políticas com as ideias liberais. Dentre elas, o tema da "liberdade religiosa" polarizou representantes do clero regalista e do catolicismo ultramontano. Atentos à historicidade comportada pela apropriação das doutrinas e pelas práticas institucionalizadas que estruturam o campo religioso, o presente artigo analisa uma polêmica específica, que então polarizou regalistas e ultramontanos, no período regencial: a questão da vinda de protestantes ao Brasil. Particularmente, analisa as publicações de dois padres publicistas ultramontanos, que se destacaram como principais opositores à vinda de metodistas ao Brasil: Luís Gonçalves dos Santos - apelidado de "Padre Perereca" - e William Paul Tilbury, sacerdote inglês que emigrara para o Brasil e aqui mudara de nome para Guilherme Paulo Tilbury. Do ponto de vista teórico, apoia-se na pertinência do instrumental teórico de Pierre Bourdieu, ao tratar da configuração do "campo religioso" no Brasil da primeira metade do século XIX, revelando a natureza das disputas pelo capital simbólico, entretecidas aos modelos alternativos de relacionamento entre Estado e Igreja.

Keywords: Ultramontanism; Protestantism; Church; State.

Palavras-chave: ultramontanismo; protestantismo; metodismo; Igreja; Estado.

\section{Introduction}

The multiple transformations that took place during the eighteenth and nineteenth centuries consecrated our entry into political modernism, a phenomenon marked by the configuration of the new political order in the framework of the modern constitutional state and democracy. A process marked by the secularization of Western societies, through which occurred the progressive autonomization of the social spheres in relation to religion. 
Although such a process appears to be associated with the "collapse of religion,"1 or the "weakening of relations with transcendence,"2 the recent historiography shows us the opposite. That is to say, secularization does not constitute a phenomenon marked by purely political disputes, nor by a defense of freedom of conscience or even the search for the secularity of the state as opposed to religion. These are transformations that at the same time respond and demand the adaptation and reformulation of religion in new terms, the result of specific historical conditions, which have informed the complex combinations between the loss of the dominion of the great religious systems and the reconfigurations of religion by Societies that continued to claim it as a condition to think of themselves as autonomous. ${ }^{3}$

In this perspective, the critique of religion (generally called "anti-clericalism") and the subsequent institutional separation between the Church and the State did not express a monolithic course, by means of which the temporal substitution of the spiritual power was gradually replaced. ${ }^{4}$ On the contrary, if the State has proceeded to "encompass the functions that were previously of the Church", guiding social cohesion no longer in "religious precepts", but in a "political ethic", one must pay attention to the singular fact that Ethics "came only from religion itself". 5

In the course of this process, the defense of religious freedom - recognized as "one of the most striking effects of secularization"6 - and the neutrality of the state in this direction, has been highlighted, shown by the adapted appropriation of three great normative principles defended by the liberal episteme in the political-religious field:

That religious subjects and convictions concerned the private spheres of groups and individuals; The neutrality of the State in the face of disputes over the truthfulness of religious questions; and the separation between church and

\footnotetext{
1 HAUPT, Heinz-Gerherd. Religião e nação na Europa no século XIX: algumas notas comparativas. Estudos Avançados, São Paulo, v. 22, n. 62, 2008. p. 77-94 (Accessed Oct 10, 2015). Avaliable from: $<$ http://www.scielo.br $>$.

2 SOUZA, José Carlos Aguiar de. As filosofias da história e a tese da secularização: a teologia cristã e as raízes da secularização na modernidade. PLURA, Revista de Estudos de Religião, v. 2, n. 2, 2011. p.43-57.

3 HERVIEU-LÉGER, Daniéle. El peregrino y el convertido: La religión en movimiento. México: Ediciones del Helénico, 2004. p. 37.

${ }^{4}$ SOUZA, José Carlos Aguiar de, Op. Cit., p. 43-57.

5 PIRES, Tiago. Revisitando a historiografia eclesiástica. A superação de uma narrativa eusebiana. In: BUARQUE, Virgínia A. Castro (org.). História da Historiografia Religiosa. Ouro Preto: EDUFOP/PPGHIS, 2012. p. 33.

${ }^{6}$ FERREIRA, Ismael de Vasconcelos. Pentecostalismo e secularização: da rigidez doutrinária ao pluralismo religioso. Horizonte, Belo Horizonte, v. 10, n. 28, p. 1462, out-dez. 2012.
} 
state, in the sense of the institutional autonomy of one domain in relation to the other".

By informing different models of secularization, such principles led to a loss of the monopoly in the production and circulation of sacred capital by previous official religions, imposing on secularized states the guarantee of legal protection for all beliefs, cults, ceremonies, liturgies and doctrines, including the right of religious groups to tax exemption.

The legal conditions for the establishment of a secular state in Brazil came with the 1891 Constitution, which put an end to the patronage, imposing the process of institutional separation between the Catholic Church and the national state. In the text revised and modified by the jurist Rui Barbosa (1849-1923) - a secularist advocate who was widely accepted in the Republican period, by associating religious freedom with "the traces of liberal thought that affirmed the principle of autonomy of the individual" and "independence of reason" ${ }^{8}$ - it was stipulated that all individuals and religious confessions could, from then on, "publicly and freely exercise their worship, associating for that purpose and acquiring goods, as long as it was within the provisions of ordinary law". 9

For our interests, it is worth emphasizing that, despite the late institutional break between the Throne and the Altar, the theme of religious freedom had gained scope previously. If, in the last decades of the nineteenth century, it was in the wake that secularization that postulated "the most radical rupture between the citizen and the believer" - understanding Church and State as "absolutely independent" entities, temporal power to guarantee complete "freedom of conscience" coupled with "parity of opportunity for all religious groups" - even during the sessions of the 1823 Constituent Assembly the positions were polarized between:

On the one hand, those who proposed a direct application in Brazilian law of the position already enshrined in liberal doctrine, and, on the other hand, those who argued that Brazil agreed on limits and restrictions greater than those

\footnotetext{
7 SOUZA, Françoise Jean de Oliveira. Do Altar à Tribuna. Os Padres Políticos na Formação do Estado Nacional Brasileiro (1823-1841). (Phd thesis) Rio de Janeiro: Universidade Estadual do Rio de Janeiro, 2010. p. 324.

8 CIARALLO, Gilson. 0 tema da liberdade religiosa na politica brasileira do século XIX: uma via para a compreensão da secularização da esfera política. Revista de Sociologia e Política, v. 19, n. 38, fev. 2011. p. 95.

9 BALEEIRO, A. (org.). Constituições Brasileiras: 1891. Brasilia: Senado Federal e Ministério da Ciência e Tecnologia, Centro de Estudos Estratégicos, 2001. p. 96.
} 
determined by the political systems of the countries that were the Cradles of liberalism..$^{10}$

At that time, two consensuses were obtained and later incorporated into the Constitution established in 1824. The first was the "adoption of Catholicism as the official religion of the Brazilian Empire", based on the understanding that religion was "the safest means of maintaining society within itself". The second was the refusal to "any kind of religious persecution, in the same way as those carried out by the Holy Inquisition"."1 Thus, the skillful way of reconciling these two unanimities would be to establish a public law capable of stipulating the tolerance of the heterodox, and at the same time regulating the limits to the exercise of full religious freedom, since "religion is a subject of eminent social interest".

During these debates, one of the main concerns among the defenders of the official and hegemonic condition of Catholicism as a cement of the political society under construction, revolved around the presence of Protestants in Brazil, until then regulated by the Treaty of 1810, signed with England, which established the freedom of worship for foreign Protestants with the prohibition of proselytism.

In this regard, most of our early constituents agreed that the insignificant number of Protestants in Brazil represented no "threat to the interests of the state." Anchored in defending the commitment to liberal principles and the experiences of those countries which, being the cradle of liberalism, instituted freedom of religion as a way of appeasing internal conflicts, they conceived this last measure as essential for solving more "a very concrete problem. Important for the national future: the settlement of the country through European immigration"..12

However, despite this provision, "the constitution of 1824 was much less advanced in the religious freedom aspect than most constituents of 1823 wanted".13 Thus, while his article 5 preserved the official condition of the Roman Catholic Apostolic religion, and its article 179 condemned any persecution "for reasons of religion, since it respects that of the State and does not offend public morals", the other religions were franked only to

10 PEREIRA, Rodrigo da Nóbrega Moura. A salvação do Brasil: as missões protestantes e o debate políticoreligioso do século XIX. (Phd thesis. Rio de Janeiro: Universidade Estadual do Rio de Janeiro, 2008. p. 66.

${ }^{11}$ Ibidem, 67.

${ }^{12}$ Ibidem, 73.

${ }^{13}$ Loc. cit. 
domestic or private worship, and to Protestantism it was not granted any advantage over any other creed..$^{14}$ According to Pereira:

Protestants did not have their political and civil rights guaranteed. The limitations on the construction of temples and the advertising of religious services remained the same as those of the 1810 treaty. On the other hand, the Constitution silenced censorship of religious ideas, proselytism, and the conversion of Brazilians to heterodox creeds. ${ }^{15}$

Like other members of the imperial elite, the Brazilian political clergy became deeply involved in this debate, articulating religion and politics in modeling new national projects. As Souza points out, "the clergy was an important political agent during the period in which the conflicts that resulted in the political emancipation of Brazil were processed", ${ }^{16}$ thus remaining in post-independence, when it assumed a significant presence in Parliament and other representative bodies. In addition, he had acted in noninstitutional ways, such as the press, expressing himself on plural issues.

Although it did not constitute a homogeneous body - whether in terms of priestly formation, secular matters or symbolic disputes - between 1827 and 1837, imperial politics and the issues of clerical reform were under the hegemony of a model of relationship between State and Church $^{17}$, conceived by a group of clergymen influenced by the regalist side of Portuguese-Brazilian secularization which, in Portugal and its domains, "perpetuated the patronage's right with the fusion between State and Church." 18 Under it, if on the one hand the Crown had an obligation to help the Church, on the other hand, it acquired marked privileges in its control. Among them, the nomination of candidates for Episcopal appointments, parish priests and chaplains; and the administration of ecclesiastical tithes, in addition to the king's power to censor the papal bulls and letters.

The patronage thus represented the strength of the Portuguese-Brazilian Catholic mentality - its cultural base and foundation of legitimization of any form of government , which unfolded in the secular action of the Church in Brazil, rendering the religious and political spheres practically inseparable, thus, collaborating to weaken the institutional

\footnotetext{
${ }^{14}$ NOGUEIRA, Octaciano (org.). Constituições Brasileiras: 1824. Brasilia: Senado Federal e Ministério da Ciência e Tecnologia, Centro de Estudos Estratégicos, 2001. p. 80.

${ }^{15}$ PEREIRA, Rodrigo da Nóbrega Moura, Op. Cit., p. 74.

${ }^{16}$ SOUZA, Françoise Jean de Oliveira, Op. Cit., p.16.

17 SANTIROCCHI, Ítalo D.. Questão de Consciência. Os ultramontanos no Brasil e o Regalismo do Segundo Reinado (1840-1889). Belo Horizonte: Fino Traço, 2015. p.73.

18 Ibidem, p. 48-49.
} 
character of the Church in Portuguese America. Throughout the colonial period, there was no "Church subject" capable of establishing his own goals and strategies to achieve them, independently of the crown. ${ }^{19}$ Although they were distinct, politics and religion, State and Church cannot be thought separately at that moment.

However, in spite of the preponderance initially assumed by the regalist model at the level of national politics, exponents of the ultra-mountain clergy - who rescued the inheritance of the Society of Jesus in Brazil, defending the direct subordination of the Catholic Church to Rome and, in this sense, of the reform that would take effect only at the end of the Empire - were present since the first half of the nineteenth century. Polarizing their positions on the models of State and Church with those advocated by the regalist clergy - although none of the groups disregarded the importance of religion as a civilizing ingredient -, these clergymen have since fed a specific polemic subject that has strained the Brazilian religious field, becoming radicalized in the late nineteenth century: that marked by the "not always peaceful confrontation between Roman Catholicism and Protestantism, although other religious manifestations appeared that would, some of them, become significant in the Republic". ${ }^{20}$

As a reaction to the alleged "Protestant threat" - widely debated among the other members of the imperial elite - two prominent representatives of the ultramontane clergy in Brazil were mobilized: publicist Luis Gonçalves dos Santos - nicknamed "Father Perereca" - and William Paul Tilbury, an English priest who had emigrated to Brazil and here changed his name to Guilherme Paulo Tilbury. ${ }^{21}$ Using the matrices of "Iberian intolerance", ${ }^{22}$ these priests in the press of the time criticized Protestant mission or

${ }^{19}$ DI STEFANO, Roberto. De qué hablamos cuando décimos 'Iglesia'? Reflexiones sobre El uso historiográfico de um término polisémico. Ariadna Histórica. Lenguages, Conceptos, Metáforas. n.1, 2012, p. 209. For the author: "Mientras la diferenciación canónica entre clero y laicado se remonta a los orígenes del cristianismo, la conformación de la Iglesia como una entidad jurídico-política es un fenómeno relativamente reciente, fruto de un proceso de secularización que encontró en la Iglesia misma uno de sus principales agentes".

${ }^{20}$ MENDONÇA, Antonio Gouvea. República e pluralidade religiosa no Brasil. Revista USP, n. 59, 2003. p. 144163.

${ }^{21}$ William Paul Tilbury, was English and lived in Brazill, Was the presbyter of the habit of St. Peter, commander of the Order of Christ and knight of the Cross. He also taught as a public teacher of English and private English and French teacher. He converted several Protestants to Catholicism. (BLAKE, Augusto Victorino Alves Sacramento. Guilherme Paulo Tilbury. In:___org.). Diccionário bibliographico brasileiro - v. 3. Rio de Janeiro: Typographia Nacional, 1985, p. 197. Available from: < http://bd.camara.gov.br/bd/handle/bdcamara/14856>.

${ }^{22}$ Although it did not eliminate the existence of a substratum of religious tolerance resulting, in a great measure, of the repercussion of the works of European intellectuals who had been standing out since the fifteenth century in this defense - Such as the writings of Erasmus of Rotterdam and Spinoza - and which lead to the Enlightenment discourse, the sixteenth and seventeenth centuries were marked, in the Iberian 
conversion, ${ }^{23}$ as was the case with Methodists, the first Protestants to send missionaries to Brazil.

In the present article, we will try to situate these first manifestations of ultramontane criticism in the theme of religious freedom in Brazil. Therefore, the reflections that follow analyze the publications of these publicist priests, ${ }_{1}^{24}$ published in the 1830 s, when the paths leading to clerical reform were not yet obvious.

From a theoretical point of view, the controversy about the coming of Protestants to Brazil can be analyzed based on the theoretical instrumental of Pierre Bourdieu, when dealing with the configuration of the "religious field" and internal disputes that structure and inform its dynamics, in different historical contexts. In the light of contributions that analyze other Latin American quarters, it is assumed that such dissidences, even in the case observed, are no longer deeply religious movements, because they dispute the same "symbolic charge of the sacred" within the same Christian field. ${ }^{25}$

Considering that during the first half of the nineteenth century the GalicanJansenist matrices that structured the relations between State and Church in Brazil were appropriated by the royalist clergy, in the treatment of the theme of religious tolerance and other topics of Portuguese illustration we shall begin our reflections situating the terms of this debate, which polarized the Brazilian Catholic clergy.

world, by the official intolerance of any belief other than Catholic. (ROCHA, Igor Tadeu Camilo. Tolerância religiosa no mundo luso-brasileiro no periodo do Reformismo llustrado: reflexão a partir das fontes inquisitoriais": e-Hum, v. 6, 2014. p.27).

${ }^{23}$ Vieira points out that this missionary Protestantism that came to Brazil, was an orthodox Protestantism, an enemy of positivism, as the ultramontanism. (VIEIRA, Davi Gueiros. 0 protestantismo, a maçonaria e a questão religiosa no Brasil. Brasilia, DF: Editora da UnB. 1980).

${ }^{24}$ The works of these two authors in this subject are: SANTOS, Luiz Gonçalves dos. Antidoto catholico contra o veneno methodista ou refutação do segundo relatório do intitulado missionario do Rio de Janeiro. Composto pelo R.P.G. Tilbbury. Com huma analyse do annuncio do vendedor de biblias, \&tc. pelo Padre Luiz Gonçalves dos Santos. Rio de Janeiro: Imprensa Americana. 1838; SANTOS, Luiz Gonçalves dos. Desagravo do clero e do povo catholico fluminense ou refutacao das mentiras e calumnias de hum impostor que se intitula missionario do Rio de janeiro, enviado pela sociedade methodista episcopal de new-york para civilisar e converter ao christianismo os fluminenses, Etc., Etc., Etc. Rio de Janeiro: Imprensa Americana, 1837; SANTOS, Luiz Gonçalves dos. 0 catholico e o methodista, ou refutação das doutrinas hereticas e falsas, que os intitulados missionarios do Rio de Janeiro, methodistas de New York, tem vulgarisado nesta corte do imperio do Brasil por meio de huns impressos chamados tracts, com o fim de fazer proselitos para a sua seita, Etc. A que se ajunta huma Dissertação sobre o direito dos Catholicos de serem sepultados nas Igrejas e nos seus adros. Offerecida e dedicada ao Exmo. e Revmo. Senhor Scipião Domingos Fabrini... pelo padre Luiz Gonçalves dos Santos. Rio de Janeiro: Imprensa Americana, 1839. These sources were localized and digitalized in the acervus of the library Brasiliana Mindlin, in the Universidade de São Paulo.

25 DI STEFANO, Roberto Di. Disidencia Religiosa y Secularización en el Siglo XIX iberoamericano: cuestiones conceptuales y metodológicas. Projeto História, São Paulo, n. 37, dez. 2008. p. 169. 


\section{The rehabilitation of the Gallican-Jansenist theses and the ultra-mountain criticism}

In Portugal - as in other Catholic monarchies - the articulation between religious and political practice gained a specific shape from the middle of the eighteenth century, when political power began to assume absolutist forms. Since then, the patronage tended to become Regalism, "a system by which the concessions received by the kings for the maintenance of the faith were often amplified and arbitrarily modified by the state," so as to submit the Church to the imperatives of royal power. ${ }^{26}$

According to Antônio Leite, since 1750 regalism became the guiding principle of the Pombal's practice, ${ }^{27}$ promoting the dissemination of its main European variants with emphasis on "Gallicanism"28 and "Jansenism"29. His adversaries, defenders of the papal primacy, were given the designation of "ultra-mountainist" and his school of thought, "ultra-mountainism"30.

It was under the auspices of the oratories that the Galician-Jansenist doctrines and practices were introduced in Coimbra. The instrument for its dissemination was the Theology of Lyons, also called Lugdunum theology. Among the several principles proposed by this manual is that princes and Christian leaders would have the right to convene Councils and to change disciplinary points of the Church. Not surprisingly, Lyon's theology

${ }^{26}$ CASTRO, Zília Osório de. Antecedentes do Regalismo Pombalino. Estudos em homenagem a João Francisco Marques. Porto: Faculdade de Letras da Universidade do Porto, 2002.

${ }^{27}$ The author defines regalism as the "legal-religious system, which advocates the excessive intervention of the king or state in ecclesiastical life, based on the supposed duty of the monarchs to" seek the good, even spiritual, of the subjects ", placing the Church under Their dependencies. This proposal was wielded by several Protestant kings and princes - as in Germany, England and Scandinavian countries - led to declare themselves heads of their respective Churches and to separate of Rome. (LEITE, António. A ideologia pombalina: Despotismo Esclarecido e Regalismo. Brotéria, v. 114, n. 5/6, May-Jun, 1982. p. 497-498).

${ }^{28}$ "French Catholic doctrine characterized by a predominance of the State over the Catholic Church, with marked national sentiment, thus having a strong political repercussion.". (SANTIROCCHI, Ítalo, Op. Cit., p.1920).

29 Jansenism is the doctrine whose name derives from Cornelis Jansen, said Cornelius Jansenius (Acquoy, Holland 1563 - Ypres 1638), bishop of Ypres in the Belgian province of Flanders, and his disciples. It arose from the conflicts over grace: its role for salvation and the controversy about being an exclusively divine attribute (a position defended by the Council and identified to the Bañist priests, followers of the Dominican thought Domingo Bañez) or fruit of the contribution of human freedom Defended by the Molinist priests, followers of the Jesuit Luís de Molina). In the seventeenth century, the controversy was retaken by Jansênio and under the direction of the Oratorian Pascásio Quesnel, from 1684, assumed more and more the behavior of a political-religious opposition party, penetrating in Italy, Holland, and Portugal. (Ibid., pp.18-19). In addition to these variants, there is also the presence of "febronianism" and "Josephism", which is in vogue in the European world.

${ }^{30}$ According to Ítalo Domingos Santirocchi, "the word ultramontane derives from the Latin, ultra montes, which means 'beyond the mountains', that is, from the Alps." Its origin derives from medieval ecclesiastical language which denominates all non-Italian Popes. He also adds that in the eighteenth century the concept came to be used to "identify the defenders of the Church in any conflict between the temporal and spiritual powers." (SANTIROCCHI, İtalo Domingos. Uma questão de revisão de conceitos: romanização ultramontanismo - reforma. Temporalidades, v. 2, n. 2, aug/dec, 2010. p. 24). 
manual was condemned by Rome and placed in the Index in 1792. This, however, did not prevent it from becoming the third most widely read manual among Portuguese-Brazilian clerics. Another instrument for spreading Galican-Jansenist ideas was the Catechism of Montpellier - the orator François-Aimé Pouget, director of the Montepllier seminary -, adopted in substitution of Jesuit catechisms. This work predisposed the clergy and laity to the concept of daily reading of the Bible, as well as other ideas which, in the critique of orthodox Catholicism, brought them closer to Protestantism. ${ }^{31}$

Thus, under the very peculiar blend of affirmation of the absolutist power and mental aeration of the Kingdom, Pombal proceeded with a set of reforms in the teaching method taught at the University of Coimbra - based on the central criticism of the teaching method taught by the Jesuits, the "prevalence of peripatetic philosophy" - and, through the diffusion of the Galican-Jansenist matrices ${ }^{32}$, to a true "denigrating policy" of the Society of Jesus, through which Jesuits were considered "greedy, seditious, conspirators, liars, authoritarians, anti-progressists and representatives of interests of a foreign authority".33

In addition to anti-Jesuitism, the Pombal reforms made the Inquisition a "Royal Court", consecrated by the Law of April 5, 1768, which created the Royal Censory Board, with the role of a supervisory body, in charge of selecting national and foreign books, that could circulate in the country and in the colonies. An essentially "statist" censorship was thus created, in which books "atheists, Protestants, denying obedience to the Holy Father, as well as books of astrology, witchcraft, superstition, obscene books, those which misrepresent the Holy Scriptures and those of the perverted philosophers of these latter times" 34

\footnotetext{
${ }^{31}$ AZZI, Riolando. A Crise da Cristandade e o Projeto Liberal. História do Pensamento Católico no Brasil, v. II. São Paulo: Edições Paulinas, 1991.

${ }^{32}$ CARVALHO, Flávio Reis de. Um Iluminismo português? A reforma da Universidade de Coimbra (1772). São Paulo: Annablume, 2008. p. 52.

33 SANTIROCCHI, İtalo Domingos. Uma questão de revisão de conceitos, 0p. Cit., p. 51-52. An important deployment of the religious question, which preceded the educational reforms themselves, was the Law of expulsion of the Company of Jesus, of Portugal and its Domains, from 1759, "a measure that set the precedent for other European nations to follow the same example," Giving rise to a movement that culminated in the signing of the Brief Dominus ac Redemptor noster, by Pope Clement XIV (1705-1774), decreeing the universal suppression of the Society of Jesus in 1773.

${ }^{34}$ SANTOS, Cândido. Jansenismo e Antijansenismo nos finais do Antigo Regime. Porto: Edições Afrontamento, 2011. p. 952.
} 
If on one hand this "rationalization of religion" confronted some "aspects of the traditional Portuguese mentality, such as millennialisms and Sebastianism" ${ }^{15}$, on the other hand, the Pombal's policies opened the space for attitudes in defense of religious tolerance. As Rocha points out, paying tribute to the Enlightenment defense of "freedom of conscience", this theme was present "in eighteenth-century Lusophone works and thinkers, in their projects for the Kingdom and colonies as part of a desired modernization". One of the first concrete measures in this direction was the abolition of the distinction between new and old Christians promoted by Pombal by Letter dated May $26,1773 . .^{36}$

In addition, it is still possible to detect several changes in the work of the Tribunal of the Holy Office attesting a greater permeability to religious tolerance, especially those:

of proceedings, investigations and penalties, such as an end to procedural secrecy, an increase in the right to a defense, a restriction of torture and capital punishment (which could only happen after the 1774 Regiment which could only occur with direct authorization of the Crown until the definitive suppression of the courts in 1821), as well as the suppression of some crimes such as those related to 'demonic possessions' and the like, treated in this context as mere superstition and product of ignorance. ${ }^{37}$

Heir of these topics present in the Portuguese Enlightenment - which resulted in a very peculiar mixture between the Galician-Jansenist model of relationship between Church and State, anti-Jesuitism and the defense of religious tolerance - the generation of clergymen who entered the process of formation of the Brazilian national state Derived a "Christian and regalist liberalism." Represented by Antônio Diogo Feijó and his followers ${ }^{38}$, these priests defended the freedom of the Brazilian Church in the face of the universal Church, reconfiguring the royal patronage in imperial patronage and, thus,

\footnotetext{
${ }^{35}$ ROCHA, Igor Tadeu Camilo, Op. Cit., p. 21.

${ }^{36}$ In the Political Testament, D. Luis da Cunha affirmed that a third "invincible and cruelest bloodletting that the State suffers is the one given to it by the Inquisition, because daily, afraid of it, the so-called "newChristian" are leaving Portugal. This same problem was approached by Ribeiro Sanches in his exposition on the Origin of the denomination of Old Christian and New Christian in Portugal, and the causes of the continuation of these names, as well as of Jewish blindness, both texts being known by Pombal. On the subject, see: SILVA, Ana Rosa Cloclet da. Inventando a Nação. Intelectuais llustrados e Estadistas lusobrasileiros na Crise do Antigo Regime Português (1750-1822). São Paulo: HUCITEC, 2005.

${ }^{37}$ ROCHA, Igor Tadeus Camilo, Op. Cit., p.20-21. For the author, the Pombaline reforms redirected the old persecution and the inquisitorial repression to those actors that came to be seen as a triple threat - to the Throne, to the Altar and to civil society -, generally denominated of "wicked, heretics, libertines and free thinkers. "

${ }^{38}$ The Feijoist group has been associated with the priests José Custódio Dias, Manoel Joaquim do Amaral Gurgel, José Bento Leite Ferreira de Melo, José Martiniano de Alencar, Antônio Maria de Moura, among others.
} 
perpetuating the symbiotic relationship between Religious power and political hierarchy; so that if, on the one hand, the Church remained incapable of "establishing its own objectives and strategies to achieve them, independently of the crown", ${ }^{39}$ on the other hand, the structuring of the new political order and the symbolic reinforcement of their divisions proved to be a tributary of the action of these priests, which included everything from education to civil records of births, deaths, marriages and wills, attending to the welfare needs, as well as the sacraments and religious rituals. ${ }^{40}$

On the Brazilian Parliament, it was from the first legislature of the Empire, installed in 1826, that the discussions around the Church emerged more frequently and intensely, opposing to the Feijoista group the two main representatives of the ultramountain clergy. They were D. Romualdo Antonio de Seixas, archbishop of Bahia, and the Bishop of Maranhão, Marcos Antônio de Sousa, defenders of the "uncompromising Roman" model, ${ }^{41}$ which denied being the inherent patronage of the sovereignty of temporal governments, conceiving as a mere papal concession and defending the "rights of the Church" as an independent institution and even hierarchically superior to the civil power, subject only to the Holy See.

In this way, we can conclude that, just as "the Pombal reform of the State encompassed an ecclesiastical reform", ${ }^{42}$ the reforms undertaken by the clergy in Brazil during the first half of the nineteenth century involved questions internal to the Church and its priestly body, inspired by different models of secularization, at that moment polarized between the representatives of the regalist tradition and the defenders of ultramountainism. These disputes, in our view, demonstrate how the involvement of priests in politics did not necessarily constitute a departure from the fundamental objectives of religious life, but rather was "a natural consequence of the enter twining in which the politicians and the religious representatives found themselves, "in their visions of the world. ${ }^{43}$

\footnotetext{
${ }^{39}$ DI STEFANO, Roberto. Disidencia religiosa y secularización em el siglo XIX Iberoamericano, Op. Cit., p. 168169.

40 HAUCK, João Fagundes (et al). História da igreja no Brasil: ensaio de interpretação a partir do povo. Segunda época - A Igreja no Brasil no século XIX. Petrópolis: Vozes, 2008. p. 14-15.

41 DI STEFANO, Roberto. Disidencia religiosa y secularización em el siglo XIX Iberoamericano , Op. Cit., p. 168.

${ }^{42}$ SANTIROCCHI, İtalo Domingos. Uma questão de consciência, Op. Cit., p. 57.

${ }^{43}$ SOUZA, Françoise J. de 0., Op. Cit., p. 25.
} 
From this particular reading of Catholicism, which associated politics and religion at various levels and integrated the Church and the State into one body, the GalicianJansenist-inspired clergy derived a particular reappropriation of the principal arrays of Pombaline regalism, adapting them to transformations in the trajectory "from one Empire to another"; among them, the one that operated the change in the symbolic foundations of the founding concept of the Brazilian State: "the passage of a notion of Monarchy as a macro-political dimension that organizes diversity, for that which recognized it by reference to the Nation itself"..$^{4}$

Thus, if according to the arguments and reforms sustained by this group, imperial regalism rehabilitated Lusitanian regalism - leading its representatives to declare themselves "Catholics and combatants of the Holy See's interference in the ecclesial life of the country" - its foundations could no longer be the same. Therefore, while the "European regalists justified their acts based on the primitive church, the ancient emperors and customs," the Brazilian imperial government "justified their regalism based on the supposed popular acclaim that ceded sovereignty to the Emperor and the imperial constitution". ${ }^{45}$

The "external administration of the national Church was, by such a conception, the competence and right of the civil power and not a privilege granted to it." Thus any attempt from Rome to regulate Brazilian Church was seen as an attack on national sovereignty. This was the connotation bestowed by Feijo on the confirmation of the Grand Master of the Order of Christ granted to the Emperor by the Pope, giving him the title of protector of the Brazilian Church, for as he was speaking as a member of the Ecclesiastical Commission of the Chamber:

Is there, on earth, another source from which the majestic attributes, other than the fundamental laws of empires, derive? Does the pope have any deposit of temporal power with which he can cuddle the monarchs of his friends, or perhaps be able to delegate in them some particle of his spiritual power, even though it is exclusive to the priesthood? ${ }^{46}$

It was precisely this new foundation of sovereignty that led the Brazilian royalist clergy to reopen the anti-Jesuitism characteristic of the Pombal's practice. Such a position

\footnotetext{
${ }^{44}$ JANCSÓ, István (org.). Independência:História e Historiografia. São Paulo-ljuí: Hucitec/FAPESP, 2005.

45 SANTIROCCHI, italo Domingos, Uma questão de consciência, Op. Cit., p. 67.

${ }^{46}$ BRASIL. Anais da Câmara dos Deputados. Sessão de 16/10/1827, p.129. Available from: $<$ http://www.camara.gov.br>
} 
assumed importance in the context of the reinforcement of the power and authority of Rome, operating within the framework of the restoration of the old European monarchies, after the defeat of Napoleon and the establishment of the Vienna Congress. Since then, the Roman pontiff regained his states, gained strength within European politics, reestablished the Order of the Jesuits and strengthened the climate of rebirth of Catholicism.

The resumption of the resurgence of papal power, at the international level, was perceived by the representatives of the Feijó's group as a threat to the construction of the bases of the independent Brazilian State. Sharing the argument that the legitimacy of the Monarch was anchored in the Constitution, these clerics reviewed the jurisdictional powers of the Catholic Church in Brazil, following Feijó's maxim: "If the Brazilian nation lacks the strength and power it needs to Promote its prosperity without the consent of the Roman Curia, then it is not independent, it is not nation". ${ }^{47}$

Thus, advocating measures that simultaneously met the imperatives of building a sovereign state and a national Church - at that moment inseparable - the members of Feijós's group mobilized against the alternative projects that, at that moment, were competing for the production and legitimation of the monopoly of religious capital, which were perceived as "expressions of Jesuitism" in Brazil. To this end, they submitted legislative proposals against the entry of friars belonging to all foreign religious orders in the Empire, generally framed in the anti-Jesuit Pombal law of 1759.

According to Souza, consistent with the rehabilitation of this tonic of Pombal's regalism, they

(...) also fostered the dismantling of religious Orders existing in Brazil, defending the abolition of the Society of Jesus, as well as the appropriation of the assets of other Orders by the State and the admission of new congregations. These proposals arose under the allegation that the Orders were promoters of ultramontanism and the supremacy of papal power (...). ${ }^{48}$

Likewise, in their parliamentary speeches, these deputies defended the deportation of foreign friars, accused of disturbing "the established order, spreading 'absolute ideas and ideas of the Transmountain," being therefore taken by "enemies of all the lights of

47 RICCl, Magda. Assombrações de um padre regente. Diogo Antônio Feijó (1784-1843). Campinas: EDUNICAMP, 2001. p. 360.

${ }^{48}$ SOUZA, Françoise G. de 0., Op. Cit., p. 344. 
Century", "very useless and harmful", so they should be " punished for teaching ultramountainism". 49

In a session of May 17, 1828, when the authorization of the entry of foreign friars in the country was discussed, Feijo stated the following:

\begin{abstract}
What countries do they come from, and what are the political institutions of their country? They come from absolute governments, and they have maxims that are contrary to our constitutional system. These men will proclaim their maxims, not in public (because they are guarded), but in the confessionals, they do not only preach the Gospel, but preach the maxims of the absolute system that they embrace $(. . .)^{50}$
\end{abstract}

Such concern for the defense of the constitutional system was expressed by Custódio Dias, in a session of June 10 of the same year:

Do these [monks] recognize the advantages of the constitutional system? What is the country in which they have ceased to disturb public order by availing themselves and taking advantage of the fanaticism of the people? Mr. President, there is yet to be one disorder that does not involve a monk and always against the freedom of the people. ${ }^{51}$

Finally, in framing the Catholic Church "in the most traditional Pombal-inspired regalism", ${ }^{52}$ these clergymen became involved in the debate on the issue that specifically concerns us: the defense of tolerance for the non-Catholics, seen as civilizing agents necessary for the construction of the nation, as illustrated by Father Feijó, who on several occasions suggested "that the Moravian brothers"53 would be invited to educate the Brazilian Indians. ${ }^{54}$

Following this same reasoning, when in 1827 the Court of Legacy - the last instance of trial of ecclesiastical law - was put into question, but which also gave the last

${ }^{49}$ CIARALLO, Gilson, Op. Cit., p. 85-99.

${ }^{50}$ BRASIL. Anais da Câmara dos Deputados, op. cit., Sessão de 17/05/1828, p.99.

${ }^{51}$ Idem, Sessão de 10/06/1828, p.84.

${ }^{52}$ SANTIROCCHI, italo Domingos, Uma questão de Consciência, Op. Cit., pp. 67.

${ }^{53}$ Protestant segment that originated as a movement of followers of John Huss in the Community of Brothers in Bohemia around 1453. With the ban on Protestantism in Moravia in 1627, the movement moved, resurfacing in Saxony, led by Count Nicolaus Ludwig von Zinzendorf, institutionalizing under the name of Moravia Church or Unitas Fratrum, initiating the evangelizing missions. The work of the Moravians was known in Brazil, mainly, for the accomplishments with the Indians of North America. The Moravian Brothers believed that they should fulfill only the laws described in the holy scriptures and not the ones of Catholic Church orders.

${ }^{54}$ MENDONÇA, Antônio Gouvêa. 0 protestantismo no Brasil e suas encruzilhadas. Revista USP, São Paulo, n.67, sep-nov. 2005. p. 48-67. 
word on matters such as marriage, and which would have as its head a foreign clergy appointed by the Pope, Diplomatic representative of Rome, under the position of Apostolic Nuncio - Custódio Dias stands as follows:

\begin{abstract}
Two centers of temporal power are incompatible in one state. Spiritual punishment is not a matter of imposing temporal penalties, and the Roman Pontiff himself and his delegates will not subject the individuals of our nation to their domination. We legislators of mortal life, allowed and permitted all religions with their domestic worship, we only know a circle in civil society and only one center..$^{55}$
\end{abstract}

The passage highlights that from the point of view of the regal clergy, it was not a question of defending complete religious freedom in Brazil, associated with the freedom of public worship to other Christian denominations. Although this was the posture posed by the liberals of the Empire at the moment when the third path of secularization emerged on the national scene - which advocated the model of the secular state, defending the most unrestricted "notion of freedom, including religious" and opposed to Catholic traditionalism - mention of the tolerance of Protestants and the encouragement of their establishment in Brazil was sufficient for representatives of ultra-mountainism to mobilize in a combative manner, guided by the following objectives:

\footnotetext{
Effort to strengthen pontifical authority over local churches; Reaffirmation of scholasticism; Restoration of the Company of Jesus (1814); And definition of the 'dangers' that plagued the Church (Gallicanism, Jansenism, regalism, all kinds of liberalism, Protestantism, Freemasonry, deism, rationalism, socialism, civil marriage, freedom of the press and more. ${ }^{56}$
}

Under such emphasis, they not only criticized internally regalism, but opposed any tendency associated with anticlerical liberalism, Freemasonry, and scientific philosophical thought, which were contrary to the principles of the Roman Church. Thus, as early as July 1826, when Congressman José Clemente Pereira presented to the Chamber a bill that regulated the exercise of freedom of the press with regard to matters related to religion, the Archbishop of Bahia and deputy Elected by the province of Pará, D. Romualdo Antônio de Seixas, agreed to the terms of Article 2, paragraph 4 of the law of freedom of the press,

${ }^{55}$ BRASIL. Anais da Câmara dos Deputados. Sessão de 25/08/1827, p. 237. Available from: $<$ http://www.camara.gov.br> (our highlights).

56 SANTIROCCHI, İtalo Domingos, Uma questão de consciência, Op. Cit., p. 161. 
which provided for punishment of "Direct attacks on religion and its dogmas, Public morality "in the following terms:

\begin{abstract}
$1^{\text {st }}$ Denying the truth of everything, or some dogmas defined by the Roman Catholic Church. $2^{\text {nd }}$ Establishing or defending false dogmas. $3^{\text {rd }}$ Blaspheming God. $4^{\text {th }}$ Mocking his saints, or religious worship approved by the same church. Those responsible in any of the first three cases will be sentenced to imprisonment for one to three years, and in the latter case imprisonment for two to six months, according to the degree of their imputation. ${ }^{57}$
\end{abstract}

After all, as the most prominent representative of Ultra-mountainism in the Chamber of Deputies, he argued that the characterization of dogmas should come from the Church, the only "Column and firmament of the truth(...). It is without a doubt a perfect society, that is, a society which has in itself all that is necessary for its conservation and to reach the ends of its divine establishment" .58

For our purposes, it is worth emphasizing that the bill on freedom of the press, in which Dom Romualdo de Seixas favorably positioned himself, was part of a context in which, admittedly, both regalists and Ultra-mountainists, were present not only in the instances of political representation, but also in non-institutional ways to promote their discourses in the fight against alternative models of Church reform.

In this sense, it is worth remembering that, along with parliamentary debates, the press had also turned to the issue of "parity of opportunity for all religious groups", linking it both to new ideas and conceptions about "freedom of conscience" and of "political freedom", 59 as to the liturgical visions of the world, which insisted on defending the hegemony of the Catholic religion.

Given the initial hegemony of the Feijo group at the level of the Brazilian Parliament - making the ultra-mountain performance unprofitable and reactive, as for "projects aimed at modernizing religion, according to liberal dictates"60 - it was in the press that circulated one of the most controversial debates, which polarized the clergy at that time: the defense of the abolition of clerical celibacy, supported by Father Feijó, vehemently challenged by Father Luis Gonçalves dos Santos.

\footnotetext{
${ }^{57}$ BRASIL. Anais da Câmara dos Deputados, op. cit., Sessão de 08 de julho de 1826, p. 93.

58 Ibidem. p. 94, 95.

${ }^{59}$ DI STEFANO, Roberto. Disidencia religiosa y secularización em el siglo XIX Iberoamericano, Op. Cit., p. 169.

60 SOUZA, Françoise J. de 0., Op.. Cit., p. 397.
} 
Although favorable to the sacramental life, Feijó and his entourage of regalist priests linked the abolition of celibacy - conceived as a disciplinary subject of the Church - to the moralization of the clergy - that would cease to live in concubinage - and, consequently, to the very vigor of the Brazilian society. The first proposal in this sense occurred during the Constituent Assembly of 1823, when Congressman Ferreira França proposed the abolition of celibacy.

Leading an even more audacious campaign in 1827, Feijó sent the General Council of the Province of São Paulo a project proposing in the same direction, starting from the distinction between dogma and ecclesiastical discipline, believing that "the latter could be changed according to times and places", adjusting to the circumstances of Brazil and passing through the scrutiny of civil power. ${ }^{61}$

In the opposite field of clerical thinking, Luiz Gonçalves dos Santos reacted to Feijó's "matchmaking projects", publishing the text "Defense of Clerical Celibacy against the separate vote of Fr. Diogo Antônio Feijó, member of the Ecclesiastical Commission of the Chamber of Deputies". ${ }^{62}$ In this document, he defended celibacy as an "apostolic institution," accusing Feijó of "sustaining Calvinist doctrines" and relying on "impious writers", broadcast by the University of Coimbra. ${ }^{63}$ In response to Perereca, Feijó published "Feijó's Response to Parvoes, Impulses and Contradictions of Father Luiz Gonçalves dos Santos" 64 accusing his opponent of being "fanatic, superstitious, papist and ultramountain".

By assuming this position, Feijo is called by Santos on several occasions as a "heretic" for "easily forgetting his oath, and... encouraging himself to make an indication contrary to, and eversive to, the maintenance of the same Religion".65

As can be seen, in order to overthrow its competitors in the political-religious field, Luis Gonçalves dos Santos used symbolic associations between regalism and Protestantism. In this sense, the criticism of Feijó's supposed "heresy" would be repeated

\footnotetext{
61 Ibidem, p. 324.

62 SANTOS, Luiz Gonçalves dos. Réplica Católica à resposta que o reverendo Senhor Deputado Feijó deu ao Padre Luis Gonçalves dos Santos. Rio de Janeiro: Typographia de Torres, 1827.

${ }^{63}$ It is worth noting that Feijo did not attend the Reformed University of Coimbra, where the Galicanist theses spread from the Pombaline reforms. Contrary to this tendency common to the majority of the liberal clergymen who acted in the formation of the Brazilian State, its formation occurred in the Village of Itu, next to the Patrocinist priests.

${ }^{64}$ FEIJÓ, Diogo Antônio. Resposta do Deputado Feijó às Parvoíces, Impiedades e Contradições do Padre Luiz Gonçalves dos Santos. In: CALDEIRA, Jorge (org.). Diogo Antônio Feijó. São Paulo: Editora 34, 1999. p. 342. 65 SANTOS, Luiz Gonçalves dos. Réplica Católica à resposta que o reverendo Senhor Deputado Feijó deu ao Padre Luís Gonçalves dos Santos, Op. Cit., p. 3.
} 
against the Methodists established in Brazil, revealing how much such a dispute was about the same "symbolic Christian capital." In this sense, the tolerant stance of the regalist clergy in relation to other Christian denominations was pointed out as a defense of religious freedom and, therefore, a threat to Catholic hegemony.

In the following reflections, we will try to present the ultra-mountain criticism of Fathers Luis Gonçalves dos Santos and Guilherme Tilbury (as the pamphlets were signed) to the issue of religious freedom in Brazil, systematized around arguments that denounced unconstitutional proselytizing and supposed Methodist heresy, threatening what was taken as the only true religion: Catholicism.

\section{The opinion press against the coming of Protestants to Brazil}

Since 1808, the question of religious tolerance had gained space in Brazilian society. This is because the transfer of the Court to Rio de Janeiro, accompanied by the effects of the opening of ports and the flagrant dependence of Portugal on England reiterated in different treaties - opened the conditions for Protestant foreigners to settle in Brazil, ${ }^{66}$ a situation that demanded a more tolerant posture of the inhabitants of America - still Portuguese - in relation to the confessions of another faith. ${ }^{67}$ But it was as of 1824, with the Imperial Constitution, that they began to call themselves "Protestants" and to hold the first cults, supported by the Brazilian Constitution's "freedom of domestic worship" to other religions.

During the nineteenth century, Protestantism that arrived in Brazil was characterized as mission or conversion, originating in the American movement known as the Great Awakening, which had begun in 1734, and in the Great Revival, which began in 1795. These movements were ideologically linked to an incursion into the American West, consisting of two main points: "the principle of conversion", which relied on regeneration, or new birth, which resulted in individual salvation, and devotion to work ethics as well as moral discipline; two levers for the ideology of progress. ${ }^{68}$

\footnotetext{
${ }^{66}$ Boanerges Ribeiro points that, in 1810, Swedish workers had been hired, who were probably lutheran. (RIBEIRO, Boanerges. Protestantismo no Brasil monárquico (1822-1888): aspectos culturais da aceitação do protestantismo no Brasil. São Paulo: Pioneira, 1973. p. 79).

${ }^{67}$ MENDONÇA, Antonio Gouvea. O celeste porvir: a inserção do protestantismo no Brasil. São Paulo, SP: ASTE, 1995.

68 Ibidem, p. 54.
} 
It was with this thought of missionary Protestantism that the first Methodist missionaries arrived in Brazil in the 1830s. ${ }^{69}$ In 1835, Reverend Fountain Elliot Pitts ${ }^{70}$ of the Board of Mission of the Methodist Episcopal Church in the United States came to Rio to preach in homes. The following year, in response to Pitts' appeals, another missionary settled in Rio de Janeiro, Reverend Justus Spaulding ${ }^{71}$, with the mission of organizing a Church, which had forty members, all of them foreigners. He was the missionary who spent more time in Brazilian lands between 1836 and 1841. In addition to the establishment of the Church, Spaulding opened a Sunday school with thirty students, including Brazilians.

In 1837, Daniel Parish Kidder ${ }^{72}$, of the American Bible Society, came to reinforce Spaulding's mission, standing out as a major distributor of Bibles. In the accounts of his travels through various provinces of the Empire between 1837 and 1840, he recorded tolerant reception by the popular strata and even by members of the literate elite, including "several priests who appreciated the gracious offerings of the Holy Scriptures," noting that he had "found The least obstacle or received the slightest disregard on the part of the people". ${ }^{73}$

Despite the ease of this attempt to fix Methodists, the first mission was shortlived, ending its activities in 1842. There are some possible reasons for closing these activities, but the most likely would be the crisis of Protestant churches in the United States, $^{74}$ which hit the Methodist Church in 1844, the year that in Brazil coincided with the beginning of the ultra-mountain reforms of the Seminaries in a tridentine way. Thus,

\footnotetext{
${ }^{69}$ In Rio de Janeiro, German and English foreigners built their first chapels, but there is no mission action by foreign communities.

${ }^{70}$ Fountain E. Pitts, pioneer in Methodist missions in South America, was a member of the Tennessee Annual Conference. He arrived in Brazil on August 19, 1835, preached in private homes and continued his missionary work in Montevideo and Buenos Aires, returning to the United States in the spring of 1836. (KENNEDY, James L.. Cinquenta annos de methodismo no Brasil. São Paulo: Methodista, 1928).

71 Justus Spaulding was a member of the New England Annual Conference and is considered the prime minister of the Southern Methodist Episcopal Church.

${ }^{72}$ Daniel Parish Kidder chegou ao Brasil em 1837, com apenas 22 anos de idade, onde permaneceu até 1840. Sua missão em solo brasileiro resultou na publicação de três livros sobre o país.Daniel Parish Kidder arrived in Brazil in 1837, only 22 years old, where he remained until 1840. His mission on Brazilian soil resulted in the publication of three books on the country.

${ }^{73}$ KIDDER, Daniel Parish. Reminiscências de viagens e permanência no Brasil, Tradução Moacyr N. Vasconcelos. São Paulo: Martins / EDUSP, v. 2, 1972, p. 112. Apud, PEREIRA, Rodrigo da Nóbrega Moura, Op. Cit., p. 75.

${ }^{74}$ The polemic of slavery was the most significant element for the schisms of the American churches of the period. Baptists, Presbyterians, and Methodists divided internally between Southern and Northerners. (HERBERG, Will. Protestantes, católicos e judeus. São Paulo/Belo Horizonte: Itatiaia, 1962).
} 
the Methodist missions would only occur again in the 1870s, with the official installation of Rev. J. J. Ramson, relying only on foreigners in their worship services.

With the arrival of the first Methodist missionaries in Brazil, Father Perereca and Father Tilbury direct their writings against this Protestant segment. In order to do so, they took advantage of the new possibilities of circulation of ideas through the press, which gave rise to a new political figure: that of the journalist or pamphleteer. ${ }^{75}$ They were learned men, and their writings were directed mainly to matters of immediate relevance directed at the people or the nation, seeking support or attacking persons or factions. They also participated in unofficial public associations in Rio de Janeiro, being "people who joined the power of the printed word to the presence in forms of institutionalized sociability" ${ }^{76}$

In this profile, the so-called "publicist priests" fit in, and both the regalist clergy and the ultra-mountain clergy used the opinion press. ${ }^{77}$ In relation to this last tendency, between 1820 and 1840, about 11\% of the publicists belonged to the Royal Academy of Sciences of Lisbon, among which was the fierce opponent of the Methodist missionary project in Brazil, Father Luis Gonçalves dos Santos. ${ }^{78}$ Author of books, pamphlets and articles published in newspapers of the time, he became involved in plural debates, forming a central part of what he himself defined as the true "literary war" between Brazilians and Portuguese, in the context of independence. ${ }^{79}$ In the imperial period, he stood out as one of the forerunners in the controversy over the coming of Protestants to Brazil and, along with the ultra-mountainst, William Tilbury, ran against the projects then defended by the regal clergy.

According to Santirocchi, with the help of another Englishman named James Andrews, Father Tilbury "assumed the responsibility, between the years 1838-1839, to

\footnotetext{
75 MOREL, Marco. As transformações dos espaços públicos. Imprensa, atores políticos e sociabilidades na cidade imperial. (1820-1840). São Paulo: Hucitec, 2005. p. 167.

76 Ibidem, p. 171.

77 About periodist acting of Feijó, refer to: SILVA, Ana Rosa Cloclet da; LOURENÇO, Laís da Silva. Entre a política e a religião: uma análise da imprensa periódica feijoísta, na conjuntura de 1834 a 1835. Revista Brasileira de História das Religiões, v. 7, p. 207-229, 2015.

78 The Royal Academy of Sciences of Lisbon was founded in 1779, as the main instance of articulation of Portuguese men and statesmen, responsible for the new phase of the Portuguese illustration and for the formulation of reformist proposals for the Kingdom and the Overseas. Because it was resistant to the Pombaline reforms - due to the rise that enabled the political discontents of the Marquis of Pombal - it was, parallel to Coimbra, a school of power, where conservative thought found redoubt.(MOREL, Marco, Op. Cit).

$79 \quad$ Beyond the pamphlets conveyed by the priests Perereca and Tilbury, the periodical press stood out in this criticism to the Methodists. As early as 1838, two weekly newspapers were edited for this purpose: 0 Católico, later reissued as 0 Católico Fluminense.
} 
read all Protestant missionary publications in English in search of news about Methodist work in Brazil," publishing them in the newspapers of Rio de Janeiro "in order to inform Catholics and provoke their reaction". ${ }^{80}$ Father Tilbury was also responsible for changing a legislative bill in Sao Paulo to include hundreds of bibles edited by Protestants, material dedicated to public education in the province, which would be provided by Methodist Daniel P. Kidder. ${ }^{81}$

In defense of the hegemonic position of the Catholic Church in Brazil, Father Perereca used political and theological arguments. A clear example of this is his refutation of Spaulding's correspondence - called the "missionary of Rio de Janeiro" - to the "Society of Missions of the Methodist Episcopal Church of New York," in which the Rev. declared: "Soon after my arrival, I began the religious service for the public, in my house". ${ }^{2}$ Likewise, the contents of tracts - pamphlets with proselytizing content that the Methodists distributed publicly - were subject to the ultra-mountain critics, as well as a bible sales announcement, published in the Jornal do Commercio by the Reverend Kidder.

According to Luis Gonçalves dos Santos, with such practices the Methodists would be circumventing Article 5. Of the Constitution, as well as $\S$ V. of Article 179 which, respectively, crossed the freedom of domestic worship to other religions, but kept them from erecting public temples, being this monopoly of the Catholic Church. As the "public" could not be framed as "domestic worship," such a practice was unconstitutional. As he himself argued:

If the Methodist said: For my family and for those of my fellowship, it is allowed by the Constitution; But for the public, no. What is meant by the word "public"? The People of Rio de Janeiro! What is the Religion of this People? The Catholic we all swear to keep. Therefore, the Methodist did not respect the Religion of the State as ordered by $\S$ V. of Article 179, raised altar against altar projecting to separate the sheep of J. C. of the flock in which they are, and rob them from the legitimate Shepherd. ${ }^{83}$

\footnotetext{
${ }^{80}$ SANTIROCCHI, İtalo Domingos. Uma questão de consciência, Op. Cit., p. 75.

81 "The Bishop of São Paulo, a former student of the University of Coimbra, Bishop Joaquim Gonçalves de Andrade, who was also a member of the provincial legislature, voted in favor of accepting the gift. However, receiving communication from Father Tilbury that these were "bogus" Bibles, so informed the legislativa paulista and the project was shelved".(VIEIRA, Davi Gueiros, Op. Cit., p. 35).

82 SANTOS, Luís Gonçalves dos. Desagravo do clero e do povo catholico fluminense ou refutacao das mentiras e calumnias de hum impostor que se intitula missionario do Rio de Janeiro, enviado pela sociedade methodista episcopal de new-york para civilisar e converter ao [...]. Rio de Janeiro: Imprensa Americana, 1837. p. 8.

${ }^{83}$ SANTOS, Luis Gonçalves dos, Loc. Cit. (our highlights).
} 
The section in bold allows us to identify the meaning of the disputes that then opposed representatives of the ultra-mountain clergy and those who professed another faith (in this case, Protestant Methodists), as well as their Catholic supporters, represented by the royalist clergy. This is Bourdieu's classic dispute between orthodoxy and heresy, ${ }^{84}$ a particular point in the struggle for the continuation of the monopoly that a particular religion holds. ${ }^{85}$ In the case in question, Luis Gonçalves dos Santos raised this accusation to the Methodist missionary, rescuing in the beginnings of the Catholic Church the presence of heretical positions. According to him:

\begin{abstract}
We find in the Acts and in the Epistles of the Apostles the names of a Simon Magus, of a Diotrephes, and several others, who openly opposed the doctrine of the Apostles, and who took their recklessness to the point of making a separate sect not wanting to communicate with those same ones, who had taught them the Evangelical doctrine. Since then, these false brethren have been known in the Church by the name of heretics, that is, by sectarians of a particular doctrine opposed to the doctrine of the Church. The Apostles immediately treated them as enemies of $\mathrm{J}$. $\mathrm{C}$. and denounced them to the Faithful so that they may flee from them so that they would not be pervert with the false doctrines of the Novice. ${ }^{86}$
\end{abstract}

It is, in other words, a rhetoric based on Bourdieu's historically observed dynamism, whereby "every dominated practice or belief is bound to appear as profaner in so far as, by its very existence and in the absence of any intention of profanation, constitutes an objective challenge to the monopoly of the management of the sacred and, therefore, to the legitimacy of the holders of this monopoly". ${ }^{87}$

At this point, it should be pointed out that such disputes took place around the same symbolic Christian capital, which brings us back to the trend observed in other nineteenth-century Latin American quarters, which, according to historian Roberto Di

84 The concept of Heresy is linked to the beginning of Christianity. For the formulation of the canonical body of the New Testament, writings were chosen that descended directly from the teachings of Jesus, these writings were defined as "orthodox" by the nascent ecclesiastical institution, which formulated the concept of "Universal Church" in Greek is "catholic". Philosophical and theological controversies were part of this process, whose victors called the opposers of heretics (LE GOFF, Jacques; SCHMIT, Jean-Claude. Heresia. In: Dicionário temático do ocidente medieval - volume 2. Bauru/São Paulo: EDUSC/Imprensa Oficial do Estado, 2002, p. 503 - 521).

${ }^{85}$ BOURDIEU, Pierre. Gênese e estrutura do campo religioso. In: BOURDIEU, Pierre. A economia das trocas simbólicas. São Paulo: Perspectiva, 2011, 1974. p. 62.

${ }^{86}$ SANTOS, Luis Gonçalves dos 0 catholico e o methodista, ou refutação das doutrinas hereticas e falsas, que os intitulados missionarios do Rio de Janeiro, methodistas de New York, tem vulgarisado nesta corte do imperio do Brasil por meio de huns impressos chamados tracts, com o fim de fazer proselitos para a sua seita, Etc.. Rio de Janeiro: Imprensa Americana, 1839, p. VIII-IX.

${ }^{87}$ BOURDIEU, P., Op. Cit., p. 45. 
Stefano, shows how much "heresy," as well as "anticlericalism," were tendencies that shaped the dimensions of ongoing processes of secularization. ${ }^{88}$

To disqualify Methodist thought, Father Perereca turned to the Ecumenical Councils and to the personalities of the history of Catholicism who opposed heresy. ${ }^{89}$ For him, these Councils represented the way that the successors of the Apostles met to combat the emergence of dissent, in such a way that the leaders of the Church:

They assembled in councils, and discussed the new doctrines, which had given place to scandals, divisions, and schisms; Condemned the errors, anathematized their authors, and if they did not surrender to the authority of the Holy Spirit who presided over these Holy Assemblies, they were thrown out of the Church's clan [...] but when heretical errors had plowed for a considerable portion of the Catholic Church, causing great ruin to the Faithful, then formed General Assemblies, which are called Ecumenical Councils. ${ }^{90}$

The texts of the Council of Trent ${ }^{91}$ are those that most appear in the writings of the ultra-mountain priests, refuting the supposedly "heretical" contents that the Methodists brought in the tracts. By singling out the Catholic religion in relation to the others, such Councils were seen as the foundation of the true "catholicity" and of the "true Church" of Jesus Christ, while the Methodist religion was pointed out as "false", representing a true "robbery" converting Catholics to Methodism:

\begin{abstract}
Catholicity, or the Universality of the Doctrine and consequently of the Faith, is the character that distinguishes the true Church of Christ from the sects, which will separate from it. [...] because we [all Catholics] are Christians by the grace of God, and by this grace we are Catholics, because we profess the same doctrine that has always taught and teaches the Holy Catholic Church. Note that the Methodist understands by Christians only their Protestant supporters and does not want Catholics to be Christians !!! Is not this stealing the inheritance from the rightful heir??2
\end{abstract}

${ }^{88}$ DI STEFANO, Roberto, "Disidencia religiosa y secularización em el siglo XIX Iberoamericano", Op. Cit., p. 158.

${ }^{89}$ Among others, he mentioned Tertullian, Saint Augustine, Vincent de Lérins, Jacques-Benigne Bossuet, Irenaeus of Lyons, Cyprian of Carthage.

${ }^{90}$ SANTOS, Luis Gonçalves dos. O catholico e o methodista, Op. Cit., p. X.

${ }^{91}$ The Council of Trent is considered one of the most important councils of the Catholic Church, dating from 1545 to 1563, and was the longest in the history of Catholicism, in which the thought of the Protestant Reformers was discussed. In order to ascertain its content, it is worth consulting the translation of D. Ignacio Lopez de Ayala. The sacrosanct and ecumenical Council of Trent. Madrid: Ramon Ruiz, 1798.

${ }_{92}$ SANTOS, Luis Gonçalves dos. Desagravo do clero e do povo catholico fluminens, op. cit., p. 51. 
In order to disqualify the system of beliefs and Methodist practices as a religion by designating it as a mere "sect" - Father Perereca also used the argument that what would make the Catholic Church the "true Church of Jesus Christ" was the unity, reinforced by the use of a universal language - Latin,$-^{93}$ which distinguished it from the schismatic churches, which separated from it and spread in various parts of Christianity, as was the case of Protestantism, whose character, he said, was The "disunion" and therefore could not be "the Church of Jesus Christ, who both commended the Apostles to Unity. ${ }^{94}$

The interpretation that Luis Gonçalves dos Santos lent to the history of Christian churches, and particularly to the elements that supposedly founded the legitimacy and truthfulness of the Catholic religion - its unity, universality and tradition - reveal a style of writing the ecclesiastical history proper to the time when, under an apologetic and memoirist bias, "the Church was regarded as a divine, not a social institution." 95 This brought us back the inheritance first started by Eusebius of Caesarea, the first one to write about the Church from his vision of the faithful. His work exerted a great influence on the historical, confessional and secular productions, especially with the advent of modernity, when it was "retaken in the reaffirmation of the varied Christian aspects, in a period in which the dispute for the hegemony of production of religious sense is catalyzed by the comprehensiveness of the interpretive field of theology, divided between Catholics and Protestants". 96

In turn, this alleged unity of the Catholic Church defended by the representative of the ultra-mountain clergy masked the internal dissidents of the Catholic faith itself in nineteenth-century Brazil, polarized, as seen, between ultra-mountainists and regalists.

The Methodists who arrived in Brazil fought against the unity of the Catholic Church, in addition to some dogmas, doctrines and disciplines, using the so-called tracts. Father Perereca fought this position, putting it as unconstitutional, for denigrating the official religion of the Brazilian Empire, and its contents were therefore treated as heresy.

\footnotetext{
${ }^{93}$ The use of a foreign language to listeners, especially Greek and Latin, was an element of discussions between the Catholic Chur ch and the Protestant religions and is criticized in the tracs distributed by the missionary of Rio de Janeiro.

${ }^{94}$ SANTOS, Luis Gonçalves dos. 0 catholico e o methodista, Op. Cit., p. XVII.

${ }^{95}$ PIRES, Thiago, op. cit., p. 27.

${ }^{96}$ Ibidem, p. 28.
} 
According to him, the content of the tracts included: the denial of the real presence of Jesus Christ in the Eucharist and, consequently, of Transubstantiation; The challenge of the universal authority of the Pope; The recognition of only two sacraments and criticism over the remaining five; The attainment of salvation only by believing in Jesus Christ and the criticism of other practices for salvation. ${ }^{97}$ They also condemned the existence of Purgatory and the feasts for the Saints. ${ }^{98}$ Some of these matters would have been addressed by Rev. Spaulding in his correspondence, in which he also mentioned the issues of clerical celibacy, the free interpretation of the Bible, and the use of "bogus" bibles, as well as the posture of the Brazilian Catholic priesthood.

The subjects discussed in the tracts touched on the dogmas of the Catholic Church, which were opposed by Protestants in the Reformation and reaffirmed by the Council of Trent. Other points of controversy, on the other hand, touched on matters pertaining to the discipline of the clergy, as well as aspects of popular religiosity and Catholic liturgy. This is the sense of the opinion delivered by the Methodist missionary on the Feast of the Holy Spirit and of Our Lady of Glory, which he calls "Catholicism blunders", which would tend to fall into contempt, as "the lights are increasing". 99 Such criticism revisited one of the topics of illustrated criticism forged during the Pombal administration, which represented "fanaticism" and "superstition" as manifestations of popular religiosity in seventeenth-century Portugal. Father Perereca, on the other hand, characterizing a "saint Catholicism", ${ }^{100}$ which was criticized by the conservative clergy itself, arguing:

The spectacles of fireworks do not enter the liturgy of the Catholic Cult, they are signs of public rejoicing; Therefore the Methodist boldly insults the revelers, who gave this spectacle to the greater splendor of the Festivity of Our Lady of

\footnotetext{
97 SANTOS, Luis Gonçalves dos. 0 catholico e o methodista, Op. Cit., p. 10-27.

98 Ibidem, p. 72.

99 Ibidem, p. 46.
}

\begin{abstract}
${ }^{100}$ Saint Catholicism is understood here as one of the most traditional forms of Brazilian Catholicism present since the colonial period. It has popular origin, emphasizing the cult to the Saints, the importance of Festivals and the popular devotions. It has a predominantly lay character, maintaining a relative autonomy in relation to institutional Catholicism, dispensing with the presence of official representatives of the church. Saint Catholicism was strongly opposed in the process of Romanization at the end of the nineteenth century, as a result of the ultramontane reform project, when they established a "universalist Catholicism" in Brazil, characterized by a strong control over the laity and their associations and the adaptation of Brazilian Catholicism to the dictates of Rome. (TEIXEIRA, Faustino. Faces do catolicismo brasileiro contemporâneo. Revista da USP, n.67, p.14-23, 2005).
\end{abstract}


Glory, as it also slanders the Catholic Religion, which, according to him, authorizes follies or prescribes them in its Ritual. ${ }^{101}$

On the other hand, it returned the criticisms to the Methodist rituals, represented in the meetings, ${ }_{1}^{102}$ using, therefore, the report of an English traveler to the United States:

All that there [in the meeting] is represented is a burlesque, ridiculous force unworthy of the majesty of the worship of God, which at times excites laughter, others causes horror, others moves to compassion, especially when contemplating exaltation, which They elevate those poor souls seduced, to the excess of losing reason, modesty, and the feelings of their dignity with remarkable disorder of the animal economy, to take successive hours to shout, to sob, to shatter like devils, especially women. [...] hypocritical public confessions of the girls animated by the false directors to give public spectacle of their weaknesses and frivolities or to lie very purposely to receive greater caresses and praises. ${ }^{103}$

In addition to these questions, Father Perereca advanced on other disputes that were dear to the Catholic priestly body, such as the question of clerical celibacy and papal authority. Concerning celibacy, the following passage stood out, where the Methodist missionary criticized such discipline:

Although I thank you (the clergy) for oath to a state of eternal celibacy, and that because you are too holy to legally enter the Holy State of Matrimony, yet many of them have great families of children, and are not ashamed of it!104

Luis Gonçalves dos Santos refuted this statement, arguing that it was no more than a misunderstanding of the Methodist missionary, because:

The Fathers have Brothers and Sisters, Nephews and Nieces, etc., so not all it seems is; And no one is obligated to omit acts of charity because of the Pharisaic scandal. But suppose half a dozen Fathers give the public scandal, of which the Methodist accuses us, does it follow that they are all, or at least many, as he says? Do not.105

101 SANTOS, Luís Gonçalves dos. Desagravo do clero e do povo catholico fluminense, 0p. Cit., p. 46. (highlights by the author)

102 Religious meetings promoted by the Methodists in the open, sort of religious camp, where worship and conversions took place, during the expansion to the west in North America. (HERBERG, Will, Op. Cit.)

${ }^{103}$ SANTOS, Luis Gonçalves dos. Desagravo do clero e do povo catholico fluminense, 0p. Cit., p. 38-39.

104 Ibidem, p. 38.

105 Loc. Cit. 
Thus, it did not give due importance to an issue that undoubtedly affected the morality and discipline of the Brazilian clergy since colonial times - the common practice of clerical concubinage $-^{106}$ and which had been the subject of their previous disputes with Father Diogo Feijó, as seen.

In addition to the question of celibacy, Father Perereca denounced the supposed misunderstanding of the Methodist missionary regarding the issue of papal authority, which highlighted the "controversy between the Catholics of this country and the Pope about the election of a Bishop, which His Holiness refuses to confirm". ${ }^{107}$ Disqualifying the importance of the issue, ${ }^{108}$ he argued:

Let the Methodist not be confused that the Brazilians swore to be Catholics, and by the mercy of God, that they never separate from the center of unity so recommended by Jesus Christ, and that they never deny filial obedience to that common Father of the Faithful, that Supreme Shepherd that Jesus Christ before going up to heaven left on the earth to do his times, and to him who gave up his lambs and his sheep. [...] The Catholics of Rio de Janeiro, and of all Brazil, had no controversy with Pope Gregory XVI. Those who excited the controversy with their Holiness 4 to 5 years ago, and still support it with so much scandal, either are not Catholics, or do not want to continue being Catholics. ${ }^{109}$

At that time which we studied, the question of papal authority was also articulated with the question of the priesthood. For the ultra-mountain priests, the popes, being successors of St. Peter - who was placed by Jesus Christ to rule the "True Church" represented the superior authority of Catholicism. In this context, the priesthood was both sacred and hierarchical, a concept that led Father Perereca to disqualify Methodism,

${ }^{106}$ SERBIN, Kenneth. Padres, celibato e conflito social: uma história da Igreja Católica no Brasil. São Paulo: Cia das Letras, 2008.

107 SANTOS, Luis Gonçalves dos. Desagravo do clero e do povo catholico fluminense, Op. Cit., p. 41.

108 The pontificate of Gregory XVI (1831-1846) marked the affirmation and consolidation of ultramontanism in Brazil, explaining the clashes between the Roman Curia and the Brazilian regalist liberals, dominant in the political scene under Feijó rule. In this episode, the Methodist referred to the wellknown "Questão Moura". In March of 1833, Antônio Maria de Moura - of the group of Feijó - was nominated to occupy the position of bishop of Rio de Janeiro. His name, however, was denied by the Holy See under the allegation of impediments and ecclesiastical irregularities. However, it was clear that the approval slip was denied due to the priest's positioning in two projects considered offensive by the Roman Curia: the one of the Ecclesiastical Box - which forbade priests to receive conscripts from the government, the exercise of other activities - And the project on marital impediments. The Brazilian government saw this attitude of the Pope as a direct offense, since by the title of the Padroado the Brazilian government, now under the Trina Regency, had the right to appoint its bishops. The case became a diplomatic problem, which remained undefeated until at least 1835, when Feijó was elected Regent of the Empire (SANTOS, José Augusto dos. Liberalismo eclesiástico e regalista no Brasil sob o pontificado de Gregório XVI. Tese de doutorado., Roma: UNIGRE, 1971).

109 SANTOS, Luis Gonçalves dos. Desagravo do clero e do povo catholico fluminense, Op. Cit., p. 42. 
arguing that the so-called ministers are not Priests, have no Sacred Order, have not received the power to redeem Sins, nor to declare them redeemed: therefore all that they do in this respect is deceit, profanation, and wickedness. ${ }^{110}$

The above passage reveals the points of the dispute between these two Christian denominations and the requirements that officially supported the conception of what was or was not "religion" in the ultramountain perspective: priestly formation, institutionalization, power granted by a hierarchical order, besides already mentioned tradition, deposited in the Scriptures.

Father Perereca continued to justify his conception of the priesthood, directly linked to the principle of holiness:

\begin{abstract}
What is it, asks the Count de Maistre, a cult minister who calls himself Reformed? A man dressed in black who every Sunday rises to the pulpit to make some honest speeches: for this job any good man suffices. "... Protestantism, continues De Maistre, asks his Ministers only for probity; Catholicism, however, demands divinized probity, that is, holiness. ${ }^{111}$
\end{abstract}

That is to say, holiness is understood here by Father Perereca as a segment of the hierarchy - which has the Pope, the legitimate representative of the apostle Peter disqualifying Methodism, composed of lay non-priests. To substantiate these arguments, he was again using a representative of French traditionalism, who, along with De Bonald, Lamennais, Bossuet, structured a set of ideas with the aim of countering the revolutionary wave in the eighteenth century and XIX. It was Joseph de Maistre ${ }^{112}$ who, in addition to the counter-revolutionary criticism, who associated Protestantism and Revolution, was able to align a marked sense of reality with the strength of what he took as the true religion: the Catholic. Claimed by the Brazilian ultra-mountainists at the beginning of the Republic, his work was already known by the ultra-mountain priests studied here, mainly for sustaining the defense of Christianity as "the religion revealed by God in history and throughout history", which led him to defend the " Unquestionable value of tradition, of objectivity, of universal authority present in Christian civilization, "the Christian religion

110 Ibidem, p. 72.

111 Ibidem, p. 33 (highlights by the author).

112 Born in Savoy in 1753, became senator in 1788, being exiled when the French revolution arrived in Savoy. Fixing himself in Russia, he wrote his works criticizing the French revolution, conceiving it as a consequence of the processes arising from the Protestant Reformation. (MOTTA, Rodrigo Patto Sá. Paradoxos do pensamento contra-revolucionário: Joseph de Maistre. Locus-Revista de História, 2001). 
being conceived as the" foundation of all positive laws "and bearing full" legislative authority by virtue of its laws being the first". ${ }^{113}$

De Maistre's traditionalist thinking insisted that "the only valid hierarchy of values is one in which politics is subordinated to morality and morality to religion"114, arguments that explain its skillful appropriation by the ultra-mountainists of the Empire.

In the criticism of the Fathers Perereca and Tilbury to the Methodists, the controversy was still raised about the use of Protestant bibles or Catholic bibles without the notes of references, besides the free interpretation of the Sacred Scriptures. Father Tilbury argued that the Catholic Church did not forbid the Bible but the abuse of the word of God. According to him: "The Bible is publicly sold, read, and circulated freely in all the Catholic World Countries, whatever the Methodist Missionaries may wish to do".115

Father Perereca, in his first pamphlet, fought the reading of Protestant bibles and the profit made with the sale of such bibles without, however, worrying about the effectiveness of such a practice. As he justified:

Our Missionary does not impose us with the Bibles that he so much bravely does at every step, because, in addition to being very poorly translated by different Sects, and not agreeing the Texts with one another, it is a very profitable business ( $\mathrm{Sic}$ ) for them. [...] Catholic Missionaries preach the Gospel, Methodists sell the Gospel for their Neophytes to read! ${ }^{116}$

However, this picture would change when he began to oppose the announcement of Reverend Kidder, published in Jornal do Commercio, on December 15, 1837, which, according to Luis Gonçalves dos Santos, followed other similar announcements published in the previous year that promoted The sale of bibles of the Catholic priest António Pereira de Figueiredo, ${ }^{117}$ edited by Protestants, in which the explanatory notes necessary, according to the ultra-mountain cleric, were suppressed, to the understanding of the Holy Scriptures:

${ }^{113}$ CORDI, Cassiano. O Tradicionalismo na Primeira República. Tese (Doutorado em Filosofia). Rio de Janeiro: Universidade Gama Filho: Departamento de Filosofia, 1984, p. 18.

114 Ibidem, p. 18.

115 SANTOS, Luis Gonçalves dos. Antidoto catholico contra o veneno methodista, 0p. Cit., p. 12.

${ }^{116}$ SANTOS, Luis Gonçalves dos. Desagravo do clero e do povo catholico fluminense, 0p. Cit., p. 31-32.

117António Pereira de Figueiredo (1725-1797) was one of the theorists of Portuguese Regalism. He studied philosophy and theology at the Congregation of the Oratory of St. Filipe Neri in Lisbon and translated the Catholic bible into Portuguese. (SANTOS, Candido. Antonio Pereira de Figueiredo, Pombal e a Aufklãrung. Revista de História das Ideias, Coimbra, 4, p. 167-206, 1982). 
Our Portuguese Father A. Pereira did not give birth to his unpublished version of the Bible, if the Bible Society is so interested in Brazilian youth, why did he delete the Notes from the two Versions of the Wise Pereira, and printed only the Text? ${ }^{118}$

Additionally, this ad directed the bible edited for "Masters and class directors." This question was fiercely contested by Father Perereca, for whom not all were intellectually prepared to interpret the Holy Scriptures without the help of the Catholic explanatory notes, since the biblical texts were difficult to understand. Relying on Vincent de Lérins ${ }^{119}$ work on heresy, he condemned as unforgivable a Christian who:

\begin{abstract}
Prefers his own judgment to that of the Church; and if he persevere in his error, he is a heretic, an excommunicate, a Gentile, and a publican. Such a deplorable state of Protestants from the Lutherans and Calvinists to the Methodists, who are the most modern of all, and perhaps for this reason the most stubborn in error, and daring to spread it even among Catholics! ${ }^{120}$
\end{abstract}

The free interpretation of the bible and its use in class was related to the opening of "Lectures" by the missionary of Rio de Janeiro, as well as the Sunday school of religious teaching. Even though it was not an explicit religious question, it directly affected the Catholic Church, since the clergy were directly involved with the general education of the Brazilian youth. In his correspondence, the missionary reported that he had opened a "Class"121 and disqualified the teaching in Brazil, referring to the confusion of languages present in the "Tower of Babel". 122

In our view, the opposition to the sale of the version of the bible translated by the oratory priest Antônio Pereira de Figueiredo is to a large extent due to the fact that he was one of the exponents of Pombal reformism and defender of religious tolerance in eighteenth-century Portugal - publicly opposing the "confused and dark" scholastic methods, as well as being the author of Theological Attempt (1766), and Theological Demonstration (1769), "two true pillars of Portuguese regalism", responsible for the

\footnotetext{
${ }^{118}$ SANTOS, Luis Gonçalves dos. Antidoto catholico contra o veneno methodista, Op. Cit., p. 18.

119 Vincent de Lérins was a Gaulish Catholic monk, acquainted with the Sacred Scriptures and the dogmas of the Church. He fought strongly against heresy, his main work was Pelegrini aduersam haereticos - also known as Commonitorium. He lived in a monastery on the Isle of Lérins until his death between the years 445 and 450.

${ }^{120}$ SANTOS, Luis Gonçalves dos. 0 catholico e o methodista, Op. Cit., p. XV.

121 The Methodists played an important role in public and religious education in the United States of America after the Great Revival (HERBERG, Will, Op. Cit.).

122 SANTOS, Luis Gonçalves dos. Desagravo do clero e do povo catholico fluminense, Op. Cit., p. 18.
} 
defense of the Episcopal strand of Portuguese regalism, of which he found in the bishops his fundamental instruments. ${ }^{123}$ In this case, the mention of "Sabio Pereira" sounds much more like an artifice of rhetoric, since it refers to a Portuguese enlightened, committed to the Gallican-Jansenist tendencies of Pombal regalism.

In turn, the fact that this translation was chosen and edited by Protestants, together with the proposal of its free interpretation, reinforced the symbolic association that, at that moment, the ultra-mountain clergy established between Regalism and Protestantism, and both, which came to be seen as "heresy" and "religious dissent" in nineteenth-century Brazil.

\section{Final Considerations}

The first half of the nineteenth century was a period of adaptation of the Church to ongoing political, social, and cultural changes. Therefore, much more than an institution moving towards full institutional separation from civil power, it remained closely linked to the state as a powerful link between dimensions that at that time underwent profound transformations and rearticulating.

In this perspective, far from attempting to hierarching the State and Church in degrees of dependence and/or importance, the discussion allowed to focus on the historicity of the appropriation of the doctrines and institutionalized practices that structured the political-religious field in Brazil in the first half of the nineteenth century, exposing the problems of some of the dimensions that then shaped the institutional configuration of the Catholic Church and the imperial state.

Taking into consideration the articulations between political and religious power, at the heart of the discussion about the legitimacy of political order in the modern constitutional state and political democracy, the analysis of the pamphlets published by the priests Perereca and William Tilbury allowed us to situate the beginnings of a a debate that at the end of the nineteenth century assumed an emergency in nature: the question of religious plurality and the redefinition of the model of relationship between State and Church in Brazil, through the end of the Patronage, made official by the Constitution of 1891.

123 SANTIROCCHI, Ítalo D., Op. Cit., p. 57. 
In this sense, it is worth remembering that in 1837, when the first pamphlet of Father Luis Gonçalves dos Santos was published, it also corresponded to the year in which there was a turning point in the game of imperial political forces, a movement known as the Conservative Regression which saw the rise of the paladins of the ultra-mountainism to the level of the national policy. ${ }^{124}$ Since then, the arguments and reforms supported by representatives of ultra-mountain thought, as a solution to the supposed threats to the hegemony of the Catholic religion, have reignited the theological, philosophical, and political matrices of those manifestations of counter-revolutionary thought which arose in France between the eighteenth and nineteenth century, from which a marked "Catholic traditionalism" was derived, as an orthodox alternative to the institutional and juridical changes of the period.

In the first half of the nineteenth century, such tendencies were started at the level of the spheres of representative power and new spaces of sociability inaugurated by our political modernity, polarizing the different strands of the Brazilian clergy - expressive of different models of secularization -, pointing to not only the conflicting coexistence between different models of Church reform and their relation to temporal power, but different ways of believing and interpreting the scriptures.

* This article results from the scientific initiation research "Padres polemistas ultramontanos e a questão da vinda de protestantes ao Brasil (1826-1842)", developed at the Faculty of History of PUC-Campinas, effective between July 2014 and August 2015.

Data de recebimento do Artigo: 12/10/2016

Data de aprovação do Artigo: 27/10/2016

${ }^{124}$ According to Santirocchi, one of the reasons for the political rise of the ultramontane clergy since the 1840s was the Conservative Regression and the participation of representatives of the regalist clergy in the liberal movements that instabilized the regency, which led the government to inhibit the political and party performance of the clergy. (SANTIROCCHI, İtalo D., Op. Cit., p. 120). 


\section{Primary sources}

Anais da Câmara dos Deputados. Brasília: Câmara dos Deputados. Available from: <http://www.camara.gov.br>. Accessed: Jan, 2013.

FEIJÓ, Diogo Antônio. Resposta do Deputado Feijó às Parvoíces, Impiedades e Contradições do Padre Luiz Gonçalves dos Santos. In: CALDEIRA, Jorge (org). Diogo Antônio Feijó. São Paulo: Editora 34, 1999. p. 342.

SANTOS, Luís Gonçalves dos. Antidoto catholico contra o veneno methodista ou refutação do segundo relatório do intitulado missionario do Rio de Janeiro. Composto pelo R.P.G. Tilbbury. Com huma analyse do annuncio do vendedor de biblias, Etc. pelo Padre [...]. Rio de Janeiro: Imprensa Americana, 1838.

- Desagravo do clero e do povo catholico fluminense ou refutacao das mentiras e calumnias de hum impostor que se intitula missionario do rio de janeiro, enviado pela sociedade methodista episcopal de new-york para civilisar e converter ao [...]. Rio de Janeiro: Imprensa Americana, 1837.

- O catholico e o methodista, ou refutação das doutrinas hereticas e falsas, que os intitulados missionarios do Rio de Janeiro, methodistas de New York, tem vulgarisado nesta corte do imperio do Brasil por meio de huns impressos chamados tracts, com o fim de fazer proselitos para a sua seita, Etc. A que se ajunta huma Dissertação sobre o direito dos Catholicos de serem sepultados nas Igrejas e nos seus adros. Offerecida e dedicada ao Exmo. e Revmo. Senhor Scipião Domingos Fabrini... pelo padre Luiz Gonçalves dos Santos. Rio de Janeiro: Imprensa Americana, 1839.

- Réplica Católica à resposta que o reverendo Senhor Deputado Feijó deu ao Padre Luís Gonçalves dos Santos. Rio de Janeiro: Typographia de Torres, 1827.

\section{Bibliography}

BAKER, Keith M. Introduction. In: The French Revolution and the Creation of Modern Political Culture: The political culture of the old regime. 0xford; New York: Pergamon Press, 1987. p. XI-XIII.

BLAKE, Augusto Victorino Alves Sacramento. Guilherme Paulo Tilbury. In: (org.) Diccionário bibliographico brasileiro - volume 3. Rio de Janeiro: Typographia Nacional, 1985, p. 197. Available from: $<$ http://bd.camara.gov.br/bd/handle/bdcamara/14856>. 
BARBOSA, Maria Izabel. Bossuet e a revogação do Edito de Nantes. Akrópolis-Revista, 2008

BOURDIEU, Pierre. Gênese e estrutura do campo religioso. In: A economia das trocas simbólicas. São Paulo: Perspectiva, 2011.

CIARALLO, Gilson. 0 tema da liberdade religiosa na política brasileira do século XIX: uma via para a compreensão da secularização da esfera política. Revista de Sociologia e Política, v. 19, n. 38, p. 85-99, feb. 2011.

DE AYALA, Ignacio Lopez (trad.). El sacrosanto y ecuménico Concilio de Trento. Imprenta Real: 1785.

DI STEFANO, Roberto. Disidencia religiosa y secularización en el siglo XIX Iberoamericano: cuestiones conceptuales y metodológicas. Projeto História (Revista do Programa de Estudos Pós-Graduados de História), São Paulo, n. 37, p. 157-178, 2008.

HAUCK, João Fagundes. Historia da Igreja no Brasil: ensaio de interpretação a partir do povo. Segunda época: a Igreja no Brasil no século XIX. São Paulo: Paulinas; Petrópolis, RJ: Vozes, 1992.

HAUPT, Heinz-Gerherd. Religião e nação na Europa no século XIX: algumas notas comparativas. Estudos Avançados, São Paulo, v. 22, n. 62, p. 77-94, 2008.

HERBERG, Will. Protestantes, católicos e judeus. São Paulo/Belo Horizonte: Itatiaia, 1962.

HERVIEU-LÉGER, Daniéle. El peregrino y el convertido: La religión en movimiento. México: Ediciones del Helénico, 2004.

HOORNAERT, Eduardo. Historia da Igreja no Brasil: ensaio de interpretação a partir do povo. Primeira época. São Paulo: Paulinas; Petrópolis, RJ: Vozes, 1992.

JANCSÓ, István; PIMENTA, João Paulo Garrido. Peças de um mosaico (ou apontamentos para o estudo da emergência da identidade nacional brasileira). In: MOTA, Carlos Guilherme (org.). Viagem incompleta. A experiência brasileira (1500-2000). Formação: histórias. São Paulo: SENAC, 2000. p. 127-175.

KENNEDY, James L. Cinquenta annos de methodismo no Brasil. São Paulo, Methodista, 1928.

LE GOFF, Jacques; SCHMIT, Jean-Claude. Heresia. In: Dicionário temático do ocidente medieval - volume 2. Bauru, SP: São Paulo, SP: EDUSC: Imprensa Oficial do Estado, 2002, p. 503-521.

LUSTOSA, Oscar de Figueiredo. Reformistas na Igreja do Brasil-Império. São Paulo: Universidade de São Paulo, Faculdade de Filosofia, Letras e Ciências Humanas, 1977. 
MENDONÇA, Antonio Gouvea. 0 celeste porvir: a inserção do protestantismo no Brasil. São Paulo, SP: ASTE, 1995. . 0 protestantismo no Brasil e suas encruzilhadas. Revista USP, São Paulo, n. 67, p. 48-67, setembro-novembro 2005.

. República e pluralidade religiosa no Brasil. Revista USP, 2003, n. 59: p. 144-163.

MENDONÇA, Antonio Gouvea; VELASOUES FILHO, Procoro. Introdução ao protestantismo no Brasil. São Paulo: Loyola, 1990.

MOREL, Marco. As transformações dos espaços públicos. Imprensa, atores políticos e sociabilidades na cidade imperial (1820-1840). São Paulo: Hucitec, 2005.

NOGUEIRA, Octaciano (org.). Constituições Brasileiras: 1824. Brasilia: Senado Federal e Ministério da Ciência e Tecnologia, Centro de Estudos Estratégicos, 2001.

PEREIRA, Rodrigo da Nóbrega Moura. A salvação do Brasil: as missões protestantes e o debate político-religioso do século XIX. Tese. Rio de Janeiro: Universidade Estadual do Rio de Janeiro, 2008.

PIRES, Thiago. Revisitando a Historiografia Eclesiástica: a superação de uma narrativa eusebiana. In: BUARQUE, Virgínia A. Castro (org.). História da historiografia religiosa. Ouro Preto: EDUFOP/PPGHIS, 2012, p. 27-42.

RIBEIRO, Boanerges. Protestantismo no Brasil monárquico (1822-1888): aspectos culturais da aceitação do protestantismo no Brasil. São Paulo: Pioneira, 1973.

RICCl, Magda. Assombrações de um padre regente: Diogo Antônio Feijó (1784-1843). Campinas UNICAMP, 2001.

SANTIROCCHI, İtalo Domingos. Uma questão de consciência: Os ultramontanos no Brasil e o Regalismo do Segundo Império (1840-1889). Belo Horizonte: Fino Traço/São Luis: EDFMA, 2015.

. Uma questão de revisão de conceitos: romanização - ultramontanismo - reforma. Temporalidades. Revista Discente do Programa de Pós-Graduação em historia da UFMG, v. 2, n. 2, aug/dec 2010.

SANTOS, Cândido. Antonio Pereira de Figueiredo, Pombal e a Aufklãrung. Revista de História das Ideias, Coimbra, 4, p. 167-206, 1982.

SILVA, Ana Rosa Cloclet da. Inventando a nação. Intelectuais ilustrados e estadistas lusobrasileiros na crise do Antigo Regime português. São Paulo: Hucitec, 2006. 
. E LOURENÇO, Laís da Silva. Entre a política e a religião: uma análise da imprensa periódica feijoista, na conjuntura de 1834 a 1835. Revista Brasileira de História das Religiões, v. 7, p. 207-229, 2015.

SOUZA, Françoise Jean de Oliveira. Do altar à tribuna: os padres políticos na formação do estado nacional Brasileiro (1823-1841). (Thesis). Universidade do Estado do Rio de Janeiro, Instituto de Filosofia e Ciências Humanas, 2010.

SOUZA, José Carlos Aguiar de. As filosofias da história e a tese da secularização: a teologia cristã e as raízes da secularização na modernidade. PLURA, Revista de Estudos de Religião, v. 2, n. 2, p. 43-57, 2011.

TEIXEIRA, Faustino. Faces do catolicismo brasileiro contemporâneo. Revista da USP, 67, p. 14-23, 2005.

Sociologia da religião: enfoques teóricos. Petrópolis, RJ: Vozes, 2003.

VIEIRA, Davi Gueiros. O protestantismo, a maçonaria e a questão religiosa no Brasil. Brasilia, DF: Editora da UnB, 1980. 